\title{
Democracy and the Moral Imperative to Philosophize
}

\author{
by J. F. Humphrey
}

At the heart of Cornelius Castoriadis' exploration into the adventure of modernity stands his reflections on democracy, but his thinking about democracy begins with the ancient Greeks and the polis of Athens. Indeed, in no fewer than three of his works [Figures of the Thinkable, Rising Tide of Insignificancy (The Big Sleep), and World in Fragments] Castoriadis devotes a part, entitled "Polis," to a discussion of democracy and its relation to modernity by beginning with the Greeks. In the interview, published under the title, "Unending Interrogation," and included in The Rising Tide of Insignificancy, Castoriadis clearly indicates that "the Greek case" [1] is the starting point for his reflections on democracy. Before going forward, I would draw your attention to one definition of democracy that Castoriadis provides his readers, which, as he says is "as good as any other." [2] Democracy "is the regime in which the public sphere becomes truly and effectively public-belongs to everyone, is effectively open to the participation of all."[3]

The Greek case, however, is distinguished from those societies that exist under the illusion that "there is an extrasocial source and grounding of the law."[4]

The idea that there is an extrasocial source and grounding of the law is an illusion. The law, the institution is creation of society; every society is self-instituted, but until now it has guaranteed its institution by instituting an extrasocial source of itself and of its institution. [5]

By "extrasocial source and grounding of the law," Castoriadis is referring to the practice of grounding society and the law upon the divine, gods, God, nature, or the laws of history, etc. [6] The Greek case, according to Castoriadis, represents a break with this practice. "If I put forward the Greek case, it is because it was so far as I know, the first break with this state of things, because it remains exemplary and was resumed in the West only in the eighteenth century, with the Enlightenment and the Revolution."[7] “The important thing in Ancient Greece," he continues, 
Is the effectively actual movement of instauration of the democracy, which is at the same time a philosophy in actuality, and which goes hand in hand with the birth of philosophy in the strict sense. When the demos instaurated the democracy, it was doing philosophy: it opened the question of the origin and the ground of the law. And it opened a public, social, and historical space for thought in which there are philosophers who, over long periods of time (up to and including Socrates), remained citizens. And it is starting from the failure of democracy, of the Athenian democracy, that Plato became the first to work out a "political philosophy," which is wholly grounded upon the misrecognition and occultation of the historical creativity of the collectivity. ... That "political philosophy"-like all the "political philosophies" that followed-was already nothing more than a philosophy about politics, external to politics, to the instituting activity of the collectivity.[8]

The Greeks, specifically the ancient Greeks of the Athenian polis during "the sixthand fifth-century,"[9] represent a break-sometimes Castoriadis uses the word, "rupture"[10]_and, hence, are distinguished from other societies precisely because here for the first time, according to Castoriadis, one finds a society that is radically aware of itself as having created itself and its institutions.

One must, however, proceed with caution here for Castoriadis distinguishes his reflections on Attic democracy from those typical of modern approaches to Greek civilization. ${ }^{[11]}$ For the past four or five centuries, the Greeks have been understood as an established standard that provides a paradigm or a model of virtue, democracy, philosophical thought, etc. Even more recently, on the other hand, scholarly considerations of the Greeks have been preoccupied with "the complete 'sociologization' or 'ethnologization' of the examination of Greece," $[12]$ according to which Greek culture is simply one among many-no better, no worse; there is no substantial difference between this culture and any other. "The differences between the Greeks" and other cultures, according to this view, "are only descriptive." [13] While Castoriadis agrees that this approach to Greek culture makes a great deal of sense, it also ignores an extremely important feature of Greek culture, namely, the concept of impartiality. Those cultures that exist prior to and outside of Greek culture, however, are according to Castoriadis, "instituted on a principle of strict closure" and maintain a rigid distinction between "us" and "them"; hence, "our view of the world is the only meaningful one, the 'others' are bizarre, inferior, perverse, 
evil, or unfaithful." [14] Citing Hannah Arendt, Castoriadis insists, "Impartiality enters this world with Homer."[15] (One thinks, for example, of the poet's sympathetic presentation of both Agamemnon's forces on the beach outside the walls of Troy attempting to gain entrance into the city, and Priam's inside the city who are trying to drive their enemies into the sea.) Nonetheless, "this is not just," as Castoriadis writes, “'affective' impartiality."

It is the impartiality of knowledge and understanding. The keen interest in the other starts with the Greeks. This interest is but another side of the critical examination and interrogation of their own institutions. That is to say, it is a component of the democratic and philosophical movement created by the Greeks. $\frac{[16]}{[16}$

Hence, Castoriadis calls for the elimination of these two approaches to Greek culture, i. e., that Greek society is a model or a paradigm that, while remaining unachievable for us, serves to guide us in our collective social and political actions; or that Greek society is not appreciably different from any other society and thus must be described as one would describe any other society, employing the methods of the social sciences. But, and this is the important point, for Castoriadis, Greek society is not a model; nor is it a historical instance among other historical instances. Greek society is the point of origin-our own origin. It is the $\operatorname{arche}$ from which our thinking must begin; it is the seed from which his reflections, and by implication our own reflections, germinate, mature, and bear fruit.

Greece is the social-historical locus where democracy and philosophy are created, thus, of course, it is our own origin. Insofar as the meaning and the potency of this creation are not exhausted-and I firmly believe that they are not-Greece is for us a germ, neither a "model," nor one specimen among others, but a germ. ${ }^{[17]}$

Furthermore, as the $\underline{\operatorname{arch} \bar{e}}$, Greek society is not only the point of origin for us, but Greece also orients and guides our thinking about history and politics. In this way, our reflections on the political are connected to the ancient Greeks, and specifically to the polis of Athens. Thus, Castoriadis asks, "How can we orient ourselves in history and politics?” Responding to his own question, he writes:

In a sense, Greece is obviously a presupposition of this discussion. The reasoned investigation of what is right and wrong, of the very principles that are the basis of 
our ever being able to say, beyond trivialities and traditional preconceptions, that something is right or wrong, arises for the first time in Greece. Our political questioning is, ipso facto, a continuation of the Greek position, although of course we have transcended it in many important respects and are still trying to transcend it. $[18]$

For Castoriadis, however, the instauration of democracy is also "the birth of philosophy in actuality."[19] The people, the dèmos, are doing philosophy, when, through their collective action, they institute the democratic polis, in so far as they are raising "the question of the origin and ground of the law." [20] In "the ancient Greek tongue and the political practice of the Athenians," Castoriadis identifies "three spheres of human activities" that are "universally valid" and "that the overall institution of society must both separate and articulate: the oikos, the agora, and the ekklēsia."[21] The oikos is the household-the English word, "economics" is derived from this term and means the rules or laws of the household. The oikos is the private sphere; the sphere from which the political power is excluded. As Castoriadis has it, "the domain in which, formally and in principle, the political power neither can nor should intervene."[22] Of course, as he is quick to point out even here there are limits: "penal law prohibits assaults on the life or bodily integrity of the members of one's family; even under the most conservative governments, the education of children is made mandatory."[23] The oikos, then, has the function of transforming the natural subject, the child, into a socialized, acculturated individual. Hence, the polis involves itself in the oikos to the extent that it must protect the individual and ensure that the oikos readies the individual through education to assume a role in the public life of the community.

The agora is "the marketplace and meeting point."[24] It is the sphere of free interaction between individual citizens who assemble to discuss matters of importance, "contract with one another, publish and buy books, and so on."[25] The agora presupposes that individuals are socialized and acculturated in virtue of their individual experiences in the oikos because of which they now "fit" in some respect into the activities of the agora. The agora assumes that individuals are recognized as being autonomous; hence, it is here that individuals are truly individuals who are free to interact with one another. Again, as Castoriadis emphasizes, just as the political power is excluded from the oikos, so, too, the political power has no place in 
this sphere; "formally and in principle, the political power neither can nor should intervene."[26] For this reason, Castoriadis sometimes refers to the agora as the private / public sphere. ${ }^{[27]}$ Nonetheless, even in societies most committed to freemarket, laissez-faire capitalism, Castoriadis observes, there are limits to the willingness of the polis to refrain from intervention into this sphere of human activity; most notably, the polis intercedes to protect contractual agreements, to enforce child labor laws, etc.

Finally, Castoriadis tells us that he uses the term, "ekklēsia" "metaphorically" or "symbolically," and he notes that he does not intend it as "an abuse of language."[28] In the New Testament, of course, word, "ekklēsia" is usually translated as "church," but as a number of sources indicate, "ekklēsia" is derived from two Greek words, "ek" which means "out" and "kaleo" which means "to call."[29] Quite literally, then, "ekklēsia" means to "call out," or more precisely, "calling out." Hence, in the classical period "ekklēsia" refers to "an assembly of citizens summoned by the crier"- "the legislative assembly." Since the "ekklessia" is the seat of power, Castoriadis holds that power will have to be shared between various branches of government, for example, an executive branch, a judicial branch, and a legislative branch. The "ekklessia" then is the domain of political power in the form of laws in virtue of which, the "ekklessia" intervenes in both the oikos and the agora to protect those who may suffer or have suffered harm. The law, however, will involve interpretation because the law is procedural; to apply the law to a particular case requires judgment; "there always is a question of interpretation of the law." [30] The judiciary must understand the intentions of the legislature. In the end, however, the most important feature of all three spheres of human activity, especially in the democratic society, is paideia or education; i. e., is to create autonomous individuals who can as such participate in the collective enterprises of the community.

The city must do everything possible to aid citizens in becoming effectively autonomous. This is, first of all, a condition for its existence qua democratic city: a city is made of citizens, and a citizen is someone who is "capable of governing and being governed," as Aristotle said (Politics 1252 a 16). But this is also . . a positive condition for each person to live well, this living well depending upon the "quality" of the others. And the achievement of this objective-aiding individuals to become autonomous, or paideia in the strongest and most profound meaning of the term-is 


\section{Nordicum-Mediterraneum}

impossible without substantive political decisions (which, moreover, must be made in every type of regime and in any event).

Democracy as a regime is therefore the regime that tries to achieve, as far as it possibly can, both individual and collective autonomy and the common good such as it is conceived by the collectivity concerned in each particular case.[31]

Of course, for Castoriadis, Socrates is the citizen philosopher precisely because he is no "ivory tower philosopher"; rather, he works the streets of Athens questioning his fellow citizens about virtue. ${ }^{[32]}$ Interestingly enough, Castoriadis chooses not mention in this context that in the Apology Socrates argues that his philosophical mission is justified, to borrow a term from Castoriadis himself, by an "extrasocial" source, i. e., the god, who at least in the Apology, would appear to be Apollo. To be fair both to Socrates and to Castoriadis, however, one might point out that in the context of the trial where Socrates stands accused of doing "injustice by corrupting the young, and by not believing in the gods in whom the city believes, but in other diamonia that are novel," [33] Socrates may be invoking the divine as a way of arguing against the charge that he does not believe in the gods. Regardless, Castoriadis does not seem to be thinking of the Socrates in the Apology, but rather of the Socrates who appears, for example, in the Republic. For there we truly find Socrates and his comrades instituting a polis in speech, which, as an alternative to the existing polis of Athens, serves as a critique of the existing polis and its institutions and provides a paradigm ${ }^{[34]}$ in terms of which changes might be introduced into the existing polis. Perhaps, as Socrates says in the Apology, he actually is a gadfly[35] who, even though he is unappreciated by the polis of Athens, is truly a gift to the city, because he exemplifies the citizen who questions the origin and ground of the law, and by implication the very foundations of society and its institutions. Hence, for Castoriadis, Socrates is the citizen philosopher. To be the citizen philosopher, however, is to be active in the public sphere. For Socrates, this meant being active in the agora, but not necessarily in the ekklēsia.[36]

If Socrates is the citizen philosopher for Castoriadis, Plato "is the first to work out 'a political philosophy,' which is wholly grounded upon the misrecognition and occultation of the historical creativity of the collectivity."[37] It is not clear how Castoriadis justifies this distinction between Socrates and Plato. When he talks of Socrates, is he talking about Plato's Socrates, Xenophon's Socrates, or some other 
version of Socrates? It is certainly difficult to believe that without Plato and Xenophon we would have any understanding of this enigmatic character other than a line in history noting his death in 399 b. C. E. Perhaps this Socrates is Castoriadis' own invention? Nevertheless, in so far as Plato initiates political philosophy, according to Castoriadis, he has misunderstood the nature of the enterprise; he has forgotten the fact that for Socrates philosophy is an activity, involving the doings of democratic citizenship. Instead, Plato introduces "a philosophy about politics, external to politics, to the instituting activity of the collectivity." [38] For Castoriadis, however, politics is an activity, "a collective activity." "Politics" is "not . . court intrigues or fighting among social groups over interest or positions"; rather, politics is "a collective activity whose object is the institution of society as such." [39] (One is reminded of Socrates' insistence in his defense that he does these things both for himself and for his fellow citizens.) To be sure, Plato begins "from the failure of democracy, of the Athenian democracy." [40] But precisely what does Castoriadis think is the failure of democracy? Is it the failure to "do everything possible to aid citizens in becoming effectively autonomous"? In other words, is the failure of democracy the inability to create, the unwillingness of the city to create, or the incapacity to see the importance of creating citizens who are, according to Aristotle, "capable of governing and being governed"? In still other words, is the failure of democracy the Athenian citizens' decision to execute Socrates? Whatever the case, Castoriadis apparently considers Plato's attempts to present his friend, Socrates, to readers in the form of the dialogue in an effort to make the city safe for philosophy a failure.

In Plato's defense, we might consider the tension, presented in the Republic, between the philosopher who would rule or the ruler who would become a philosopher on the one hand and the various forms of political regimes. Is there anyone who doubts that we would indeed be better off if we could actually birth and educate a perfect ruler? Here, of course, we have two problems: the birthing and the education. Perhaps if all our new found knowledge of genetics were employed, we might solve the problem of birthing the most perfect human specimen. The education, however, is certain to be more difficult. We would need to decide upon the perfect curriculum and stick to it. We would not want to be like a California school board that changes direction with every new trend in education. Once we decide on the curriculum, there is the problem of how do we deliver the curriculum. 
Microsoft PowerPoint slides? Experiential education? Theory? Praxis? Theory and praxis? How much of each? With which do we start?

In the Phaedo, Simmias provides with an interesting insight.

I think, Socrates, as perhaps you do too, that in these matters certain knowledge is either impossible or very hard to come by in this life; but that even so, not to test what is said about them in every possible way, without leaving off till one has examined them exhaustively from every aspect, shows a very feeble spirit; on these questions one must achieve one of two things: either learn or find out how things are; or, if that's impossible, then adopt the best and least refutable of human doctrines, embarking on it as a kind of raft, and risking the dangers of the voyage through life, unless on could travel more safely and with less risk, on a securer conveyance afforded by some divine doctrine (Phd. $85 \mathrm{c}-\mathrm{d}) .{ }^{[41]}$

If Simmias is correct, perhaps we should forget the attempt to birth and educate the perfect ruler. The prospect of expecting to find a student of philosophy who would want to rule or a ruler who would study philosophy may be an equally disappointing project. What remains then is the best of the worse regimes and that after all would be democracy. Is the failure of democracy also the failure of philosophy? Or is the failure of democracy a sign that despite the fact that it does not fit well with politics, philosophy is essential to democracy? Could it be that the failure of democracy-the execution of Socrates-raises the awareness of the necessity of taking philosophy to the streets as Socrates himself did, thus, ensuring the need for doing philosophy?

But what are we to do now in this age of pseudodemocracies? Here we return to Castoriadis for one last consideration.

What is at stake here, then, has nothing to do with tranquilly managing the prevailing consensus, extending the "spaces of freedom" millimeter by millimeter, or demanding "more and more rights." How this can be done is another matter. No great collective political movement can be created by the act of will of a few individuals. But as long as this collective hypnosis continues, there is a provisional ethical and political stance for those of us who have the weighty privilege of being able to speak up, namely: unmask, criticize, denounce the existing state of affairs. And for everyone: try to be exemplary in one's behavior and acts wherever one 
finds oneself. Whatever depends on us is our responsibility. [42]

For Cornelius Castoriadis, then just as for Aristotle, the political sphere and the ethical sphere cannot be separated. While those of good will can neither force social change nor force the development of a great collective political movement, the collective hypnosis into which the world has sunk still demands a political and ethical response from us who have the privilege of being able to speak. Thus, we who have the privilege of being able to speak have obligations; the privilege is weighty; hence, the obligation is equally weighty-to unmask, criticize, denounce the existing state of affairs. Wherever we find ourselves, our behavior and our acts are to be exemplary; we are responsible for whatever depends on us. Our privilege of being able to speak, then, creates political obligations that entail ethical responsibilities. We must become Socratic; we must take philosophy back to the streets!

\section{Bibliography}

Castoriadis, Cornelius. "Democracy as Procedure and Democracy as Regime" in The Rising Tide of Insignificancy (The Big Sleep), translated and edited anonymously, http://www.notbored.org/cornelius-castoriadis.html, December, 2003, pp. 329-59.

Figures of the Thinkable. Translated by Helen Arnold. Stanford, California: Stanford University Press, 2007.

"The Greek Polis and the Creation of Democracy" in Philosophy, Politics, Autonomy, Edited by David Ames Curtis, New York and Oxford: Oxford University Press, 1991. Originally published in Graduate Faculty Philosophy Journal, vol. 9, no. 2 (Fall 1983): 79-115.

Philosophy, Politics, Autonomy, Edited by David Ames Curtis, New York and Oxford: Oxford University Press, 1991.

The Rising Tide of Insignificancy (The Big Sleep), translated and edited anonymously, http://www.notbored.org/cornelius-castoriadis.html, December, 2003. 


\section{Nordicum-Mediterraneum}

"Unending Interrogation" in The Rising Tide of Insignificancy (The Big Sleep), translated and edited anonymously, http://www.notbored.org/corneliuscastoriadis.html, December, 2003, pp. 259-87.

"What is Democracy" in Figures of the Thinkable, translated by Helen Arnold, Stanford, California (Stanford University Press, 2007), pp. 118-50.

Plato, Apology, in Plato and Aristophanes, Four Texts on Socrates: Plato's

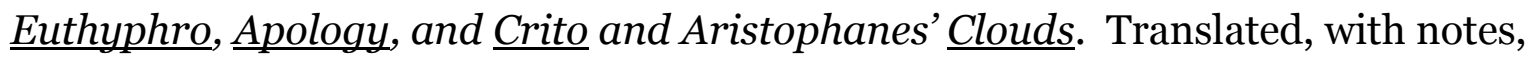
by Thomas G. West and Grace Starry West, and an Introduction by Thomas G. West. Ithaca, New York: Cornell University Press, 1990, pp. 63-97.

Plato and Aristophanes. Four Texts on Socrates: Plato's Euthyphro, $\underline{\text { Apology, and }}$ Crito and Aristophanes' Clouds. Translated, with notes, by Thomas G. West and Grace Starry West, and an Introduction by Thomas G. West. Ithaca, New York: Cornell University Press, 1990.

Plato. The Republic of Plato. Translated, with notes and an Interpretive Essay, by Allan bloom. New York, New York: basic books, Inc., 1968.

Plato, Phaedo. Translated and edited by David Gallop. Oxford and New York: Oxford University Press, 1993.

\section{Endnotes}

[1] Cornelius Castoriadis. "Unending Interrogation" in The Rising Tide of Insignificancy (The Big Sleep), translated and edited anonymously, http://www.notbored.org/cornelius-castoriadis.html, December, 2003, p. 276.

[2] Cornelius Castoriadis. "Democracy as Procedure and Democracy as Regime" in The Rising Tide of Insignificancy (The Big Sleep), translated and edited anonymously, http://www.notbored.org/cornelius-castoriadis.html, December, 2003 , p. 341.

[3] Cornelius Castoriadis. "Democracy as Procedure and Democracy as Regime" in The Rising Tide of Insignificancy (The Big Sleep), translated and edited 


\section{Nordicum-Mediterraneum}

anonymously, http://www.notbored.org/cornelius-castoriadis.html, December, 2003 , p. 341.

[4] Cornelius Castoriadis. "Unending Interrogation" in The Rising Tide of Insignificancy (The Big Sleep), translated and edited anonymously, http://www.notbored.org/cornelius-castoriadis.html, December, 2003, p. 274.

[5] Cornelius Castoriadis. "Unending Interrogation" in The Rising Tide of Insignificancy (The Big Sleep), translated and edited anonymously, http://www.notbored.org/cornelius-castoriadis.html, December, 2003, p. 274.

[6] Cornelius Castoriadis. "Unending Interrogation" in The Rising Tide of Insignificancy (The Big Sleep), translated and edited anonymously, http://www.notbored.org/cornelius-castoriadis.html, December, 2003, p. 274.

[7] Cornelius Castoriadis. "Unending Interrogation" in The Rising Tide of Insignificancy (The Big Sleep), translated and edited anonymously, http://www.notbored.org/cornelius-castoriadis.html, December, 2003, p. 276. Also, see: "Democracy as Procedure and Democracy as Regime" in The Rising Tide of Insignificancy (The Big Sleep), translated and edited anonymously, http://www.notbored.org/cornelius-castoriadis.html, December, 2003, pp. 334-35.

This type of institution of society covers almost all of human history. Here we are talking about heteronomous societies, which certainly create their own institutions and significations, but they also occult this self-creation by imputing it to an extrasocial source-in any case, one that is external to the effectively existing collectivity: the ancestors, the heroes, the gods, God, the laws of history or those of the market. In these heteronomous societies, the institution of society takes place within a closure of meaning. All questions the society under consideration is capable of formulating can find a response within its imaginary significations, and those that cannot be formulated are not so much forbidden as mentally and psychically impossible for the members of that society.

This situation, as we know, has been shattered but twice in history-in ancient Greece and in Western Europe-and we are the inheritors of this break. It is what allows us to speak as we are now speaking. The Rupture that has occurred expresses itself through the creation of politics and philosophy (or reflection). Politics puts 
into question the established institutions. Philosophy puts into question what bacon called the idola tribus, the collectively accepted representations.

[8] Cornelius Castoriadis. “Unending Interrogation," in The Rising Tide of Insignificancy (The Big Sleep), translated and edited anonymously, http://www.notbored.org/cornelius-castoriadis.html, December, 2003, pp. 276-77.

[9] Cornelius Castoriadis. "Unending Interrogation," in The Rising Tide of Insignificancy (The Big Sleep), translated and edited anonymously, http://www.notbored.org/cornelius-castoriadis.html, December, 2003, p. 277.

The pursuit of the radically critical, democratic, revolutionary movement, first by the Revolutions of the eighteenth century and during the Age of Enlightenment, then by the socialist workers' movement, presents some considerable "pluses" and "minuses" in relation to sixth-and fifth-century Greece. The "pluses" are obvious: the contestation of the instituted social imaginary by the workers' movement goes much further, challenges the effectively actual conditions of social existence-economy, labor, and so on-and universalizes itself in intending, by right, all societies and peoples. but one cannot neglect the "minuses": the moments when the movement succeeded in disengaging itself fully from the grip of instituted society were rare and above all, starting at a certain moment the movement fell, qua organized movement, under the exclusive or preponderant, even when indirect, influence of Marxism. (My italics indicated by underlining).

[10] Cornelius Castoriadis. "Democracy as Procedure, Democracy as Regime," in The Rising Tide of Insignificancy (The Big Sleep), translated and edited anonymously, http://www.notbored.org/cornelius-castoriadis.html, December, 2003, pp. 334-35.

This situation, as we know, has been shattered but twice in history-in ancient Greece and in Western Europe-and we are the inheritors of this break. It is what allows us to speak as we are now speaking. The rupture that has occurred expresses itself through the creation of politics and philosophy (or reflection). Politics puts into question the established institutions. Philosophy puts into question what bacon called the idola tribus, the collectively accepted representations.

[11] Cornelius Castoriadis, "The Greek Polis and the Creation of Democracy" in 
Philosophy, Politics, Autonomy, Edited by David Ames Curtis, New York and Oxford (Oxford University Press, 1991), pp. 82-83.

Modern discussions of Greece have been plagued by two opposite and symmetricalthus, in a sense, equivalent-preconceptions. The first, and most frequently encountered over the last four or five centuries, is Greece as eternal model, prototype, or paradigm. (One contemporary outlook merely inverts this preconception: Greece as antimodel, as negative model.) The second and more recent preconception involves the complete "sociologization" or "ethnologization" of the examination of Greece. Thus, the differences between the Greeks, the Nam bikwara, and the bamileke are only descriptive. No doubt, this second attitude is formally correct. Not only, needless to say, is there not nor could there be any difference in "human value," "worthiness," or "dignity" between different peoples and cultures, but neither could there be any objection to applying to the Greek world the methods-if there be any-applied to the Arunta or to the Babylonians.

The second approach, however, misses a minute and decisive point. The reasoned investigations of other cultures and the reflection upon them does not begin with the Arunta or the Babylonian cultures. Indeed, one could show that it could not have begun with them. Before Greece and outside the Greco-Western tradition, societies are instituted on a principle of strict closure; our view of the world is the only meaningful one, the "others" are bizarre, inferior, perverse, evil, or unfaithful. As Hannah Arendt has said, impartiality enters this world with Homer. This is not just "affective" impartiality. It is the impartiality of knowledge and understanding. The keen interest in the other starts with the Greeks. This interest is but another side of the critical examination and interrogation of their own institutions. That is to say, it is a component of the democratic and philosophical movement created by the Greeks.

That the ethnologist, the historian, or the philosopher is in a position to reflect upon societies other than his own and, indeed, even upon his own society becomes a possibility and a reality only within this particular historical tradition-the GrecoWestern tradition.

[12] Cornelius Castoriadis, "The Greek Polis and the Creation of Democracy" in Philosophy, Politics, Autonomy, Edited by David Ames Curtis, New York and Oxford 
(Oxford University Press, 1991), p. 82.

[13] Cornelius Castoriadis, "The Greek $\underline{\text { Polis }}$ and the Creation of Democracy" in Philosophy, Politics, Autonomy, Edited by David Ames Curtis, New York and Oxford (Oxford University Press, 1991), p. 82.

[14] Cornelius Castoriadis, "The Greek Polis and the Creation of Democracy" in Philosophy, Politics, Autonomy, Edited by David Ames Curtis, New York and Oxford (Oxford University Press, 1991), p. 82. Emphasis added.

[15] Cornelius Castoriadis, "The Greek Polis and the Creation of Democracy" in Philosophy, Politics, Autonomy, Edited by David Ames Curtis, New York and Oxford (Oxford University Press, 1991), p. 82. Castoriadis cites Hannah Arendt's "The Concept of History," in between Past and Future (New York: Viking Press, 1968), p. 51. It is interesting that neither Arendt nor Castoriadis appear to be troubled by the fact that the word "Greek" never appears in Homer; indeed, there are even very few uses of the word "Hellas." In the Iliad and the Odyssey, the poet refers to the people about whom he composes by their tribal names.

[16] Cornelius Castoriadis, "The Greek Polis and the Creation of Democracy" in Philosophy, Politics, Autonomy, Edited by David Ames Curtis, New York and Oxford (Oxford University Press, 1991), pp. 82-83.

[17] Cornelius Castoriadis, "The Greek $\underline{\text { Polis }}$ and the Creation of Democracy" in Philosophy, Politics, Autonomy, Edited by David Ames Curtis, New York and Oxford (Oxford University Press, 1991), p. 84.

[18] Cornelius Castoriadis, "The Greek $\underline{\text { Polis }}$ and the Creation of Democracy" in Philosophy, Politics, Autonomy, Edited by David Ames Curtis, New York and Oxford (Oxford University Press, 1991), p. 81.

[19] Cornelius Castoriadis. "Unending Interrogation," in The Rising Tide of Insignificancy (The Big Sleep), translated and edited anonymously, http://www.notbored.org/cornelius-castoriadis.html, December, 2003, p. 276.

[20] Cornelius Castoriadis, "Unending Interrogation," in The Rising Tide of Insignificancy (The Big Sleep), translated and edited anonymously, 


\section{Nordicum-Mediterraneum}

http://www.notbored.org/cornelius-castoriadis.html, December, 2003, p. 276.

[21] Cornelius Castoriadis, "Democracy as Procedure and Democracy as Regime" in The Rising Tide of Insignificancy (The Big Sleep), translated and edited anonymously, http://www.notbored.org/cornelius-castoriadis.html, December, 2003, pp. 340-41.

The ancient Greek tongue and the political practice of the Athenians offer us a precious-and, in my opinion, universally valid-distinction among three spheres of human activities that the overall institution of society must both separate and articulate: the oikos, the agora, and the ekklēsia. A free translation would be: the private sphere, the private / public sphere, and the (formally and in the strong sense) public sphere, identical to what I above called explicit power. I note in passing that this fundamental distinction is there, on a factual level and in language, but was not rendered explicit as such during the classical era, not even, except partially, by the classical thinker of democracy, Aristotle.

These spheres are clearly distinguished (and properly articulated) only under a democratic regime. Under a totalitarian regime, for example, the public sphere in principle absorbs everything. At the same time, this public sphere is in reality not at all public, for it has become the private property of the totalitarian Apparatus that holds and exercises power. In principle, traditional absolute monarchies respected the independence of the private sphere-the oikos-and intervened only moderately in the private / public sphere-the agora. Paradoxically, today's pseudodemocracies in the West have in fact rendered the public sphere in large part private: the decisions that really count are those made in secret or behind the scenes (of the Government, the parliamentary system, and the party Apparatuses). A definition of democracy as good as any other is: it is the regime in which the public sphere becomes truly and effectively public-belongs to everyone, is effectively open to the participation of all.

[22] Cornelius Castoriadis, "Democracy as Procedure and Democracy as Regime” in The Rising Tide of Insignificancy (The Big Sleep), translated and edited anonymously, http://www.notbored.org/cornelius-castoriadis.html, December, 2003 , p. 341. 
The oikos-the family household, the private sphere-is the domain in which, formally and in principle, the political power neither can not should intervene. As with all subjects in this domain, even this cannot and should not be taken absolutely: penal law prohibits assaults on the life or bodily integrity of the members of one's family: even under the most conservative governments, the education of the children is made mandatory; and so forth.

[23] Cornelius Castoriadis, "Democracy as Procedure and Democracy as Regime” in The Rising Tide of Insignificancy (The Big Sleep), translated and edited anonymously, http://www.notbored.org/cornelius-castoriadis.html, December, 2003, p. 340.

[241 Cornelius Castoriadis, "Democracy as Procedure and Democracy as Regime" in The Rising Tide of Insignificancy (The Big Sleep), translated and edited anonymously, http://www.notbored.org/cornelius-castoriadis.html, December, 2003 , p. 341.

The agora - the marketplace and meeting point-is the domain in which individuals come together freely, discuss matters, contract with one another, publish and buy books, and so on. Here again, formally and in principle, the political power neither can nor should intervene-and here again, as in all cases, this cannot be taken as absolute. The law prescribes respect for private contracts, prohibits child labor, and so on. In fact, one could never stop enumerating the points on which and the arrangements by which the political power, even in the most "liberal States (in the sense of \{ "free-market" or "Laissez-faire"\} capitalist liberalism), intervenes in this domain (for example, the formulation of governmental budgets . ...”)

[25] Cornelius Castoriadis, "Democracy as Procedure and Democracy as Regime" in The Rising Tide of Insignificancy (The Big Sleep), translated and edited anonymously, http://www.notbored.org/cornelius-castoriadis.html, December, 2003 , p. 341.

[26] Cornelius Castoriadis, "Democracy as Procedure and Democracy as Regime" in The Rising Tide of Insignificancy (The Big Sleep), translated and edited anonymously, http://www.notbored.org/cornelius-castoriadis.html, December, 2003 , p. 341. 
[27] Cornelius Castoriadis, "Democracy as Procedure and Democracy as Regime" in The Rising Tide of Insignificancy (The Big Sleep), translated and edited anonymously, http://www.notbored.org/cornelius-castoriadis.html, December, 2003, p. 340.

[28] Cornelius Castoriadis, "Democracy as Procedure and Democracy as Regime" in The Rising Tide of Insignificancy (The Big Sleep), translated and edited anonymously, http://www.notbored.org/cornelius-castoriadis.html, December, 2003, pp. 341-42.

The ekklēsia, a term I use here metaphorically, is the site of the political power, the public / public domain. The political power includes powers, and these powers must be both separate and articulated.

Also, see n. 7, p. 341.

I use this term symbolically (and not as an abuse of language). The Athenian Assembly did not exercise judicial power and only supervised the "executive" (in the sense I give here to this term, i. e., administration).

[29] Liddell and Scott define ekklesia as "an assembly of citizens summoned by the crier, the legislative assembly." [R. Scott, and H.G. Liddell, A Greek-English Lexicon, p. 206.] Thayer's lexicon says, "an assembly of the people convened at the public place of council for the purpose of deliberating" [J. H. Thayer, A Greek-English Lexicon of the New Testament, p. 196]. Trench gives the meaning as "the lawful assembly in a free Greek city of all those possessed of the rights of citizenship, for the transaction of public affairs" [R.C. Trench, Synonyms of the New Testament, 7 th ed., pp. 1-2]. Seyffert's dictionary states, "The assembly of the people, which in Greek cities had the power of final decision in public affairs" [Oskar Seyffert, A Dictionary of Classical Antiquities, pp. 202-203].From "fully after the LORD" by Steve Flinchum http://www.bryanstation.com/flinchum-fully.htm. NOTE: This information taken from: http://www.hisholychurch.net/ekklesia.html and http://en.wikipedia.org/wiki/Ecclesia.

$[30]$ Cornelius Castoriadis, "Democracy as Procedure and Democracy as Regime" in The Rising Tide of Insignificancy (The Big Sleep), translated and edited anonymously, http://www.notbored.org/cornelius-castoriadis.html, December, 
2003 , p. 342.

[31] Cornelius Castoriadis, "Democracy as Procedure and Democracy as Regime" in The Rising Tide of Insignificancy (The Big Sleep), translated and edited anonymously, http://www.notbored.org/cornelius-castoriadis.html, December, 2003 , p. 357.

[32] Plato, Apology, in Plato and Aristophanes, Four Texts on Socrates: Plato's Euthyphro, Apology, and $\underline{\text { Crito }}$ and Aristophanes' $\underline{\text { Clouds, }}$, translated, with notes, by Thomas G. West and Grace Starry West, introduction by Thomas G. West (Ithaca, New York: Cornell University Press, 1990), pp. 80-81.

So that not even if you let me go now and if you disobey Anytus-who said that either I should not have been brought in here at the beginning, or since I was brought in, that it is not possible not to kill me (he said before you that if I am acquitted, soon your sons, pursuing what Socrates teaches, will all be completely corrupted)-if you would say to me with regard to this, "Socrates, for now we will not obey Anytus; we will let you go, but on this condition: that you no longer spend time in this investigation or philosophize; and if you are caught still doing this, you will die"-if you would let me go, then, as I said, on these conditions, I would say to you, "I, men of Athens, salute you and love you, but I will obey the god rather than you; and as long as I breathe and I am able to, I will certainly not stop philosophizing, and I will exhort you and explain this to whomever of you I happen to meet, and I will speak just the sorts of things I am accustomed to: 'best of men, you are an Athenian, from the city that is greatest and best reputed for wisdom and strength: are you not ashamed that you care for having as much money as possible, and reputation, and honor, but that you neither care for nor give thought to prudence and truth and how your soul will be the best possible?' And if one of you disputes it and asserts that he does care, I will not immediately let him go, nor will I go away, but I will speak to him and examine and test him. And if he does not seem to me to possess virtue, but only says he does, I will reproach him, saying that he regards the things worth the most as the least important, and the paltrier things as more important. I will do this to whomever, younger or older, I happen to meet, both foreigner and townsman, but more so to the townsmen, inasmuch as you are closer to me in kin.

"Know well, then, that the god orders this. And $I$ suppose that until now no greater 
good has arisen for you in the city than my service to the god. For I go around and do nothing but persuade you, both younger and older, not to care for bodies and money before, nor as vehemently as, how your soul will be the best possible. I say: 'Not from money does virtue come, but from virtue comes money and all of the other good things for human beings both privately and publicly.' If, then, I corrupt the young by saying these things, they may be harmful. But if someone asserts that what I say is other than this, he speaks nonsense. With a view to these things, men of Athens," I would say, "either obey Anytus or not, and either let me go or not, since I would not do otherwise not even if I were going to die many times" (Ap. 29 c-30 c).

[33] Plato, Apology, in Plato and Aristophanes, Four Texts on Socrates: Plato's

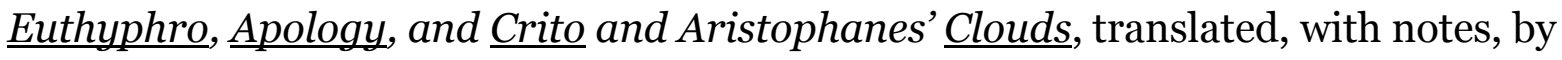
Thomas G. West and Grace Starry West, introduction by Thomas G. West (Ithaca, New York: Cornell University Press, 1990), p. 73.

So about the things which the first accusers accused me of, let this be a sufficient defense speech before you. But against Meletus, the "good and patriotic," as he says, and the later accusers, I will try to speak next in my defense. Now again, just as though these were other accusers, let us take up their sworn statement. It is something like this: it asserts that Socrates does injustice by corrupting the young, and by not believing in the gods in whom the city believes, but in other diamonia that are novel. The charge is of this sort. But let us examine each one of the parts of this charge (Ap. 24 b-c).

[34] Plato, The Republic of Plato, translated, with notes and an Interpretive Essay, by Allan bloom (New York, New York: basic books, Inc., 1968), pp. 274-75, 592 a-b. In this text, the erotic Glaucon has been pushing Socrates to explain whether or not the polis in speech can ever be an actual reality. While Socrates keeps putting off Glaucon, he finally admits that perhaps the polis is not meant to exist as an actual polis.

"I understand," he (Glaucon) said. "You mean he (the man who has intelligence) will in the city whose foundation we have now gone through, the one that has its place in speeches, since I don't suppose it exists anywhere on earth.”

"but in heaven," I (Socrates) said, “perhaps, a pattern is laid up for the man who 
wants to see and found a city within himself on the basis of what he sees. It doesn't make any difference whether it is or will be somewhere. For he would mind the things of this city alone, and of no other.” (My italics).

“That's likely," he (Glaucon) said.

[35] Plato, Apology, in Plato and Aristophanes, Four Texts on Socrates: Plato's Euthyphro, Apology, and $\underline{\text { Crito }}$ and Aristophanes' $\underline{\text { Clouds, }}$, translated, with notes, by Thomas G. West and Grace Starry West, introduction by Thomas G. West (Ithaca, New York: Cornell University Press, 1990), p. 82.

So I, men of Athens, am now far from making a defense speech on my own behalf, as someone might suppose. I do it rather on your behalf, so that you do not do something wrong concerning the gift of the god to you by voting to condemn me. For if you kill me, you will not easily discover another of my sort, who-even if it is rather ridiculous to say-has simply been set upon the city by the god, as though upon a great and well-born horse who is rather sluggish because of his great size and needs to be awakened by some gadfly. Just so, in fact, the god seems to me to have set me upon the city as someone of this sort: I awaken and persuade and reproach each one of you, and I do not stop settling down everywhere upon you the whole day. Someone else of this sort will certainly not easily arise for you, men. Well, if you obey me, you will spare me. But perhaps you may be vexed, like the drowsy when they are awakened, and if you obey Anytus and slap me, you would easily kill me. Then you would spend the rest of your lives asleep, unless the god sends you someone else in his concern for you. (Ap. $30 \mathrm{~d}-31 \mathrm{a}$ ).

[36] Plato, Apology, in Plato and Aristophanes, Four Texts on Socrates: Plato's

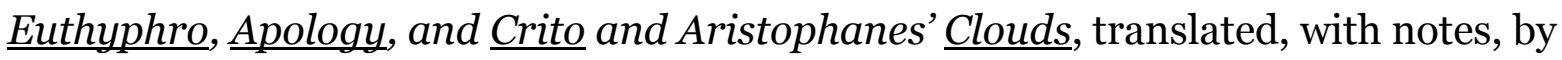
Thomas G. West and Grace Starry West, introduction by Thomas G. West (Ithaca, New York: Cornell University Press, 1990), pp. 85-86.

Do you suppose, then I would have survived so many years if I had been publicly active and had acted in a manner worthy of a good man, coming to the aid of the just things and, as one ought, regarding this as most important? Far from it, men of Athens; no would any other human being.

But through all my life, if I was ever active in public at all, it is apparent that I was 
the sort of man (and in private I was the same) who never conceded anything to anyone contrary to the just-neither to anyone else, nor to any of those who my slanderers say are my students. I have never been anyone's teacher; but if anyone whether younger or older, desired to hear me speaking and doing my own things, I never begrudged it to him. And I do not converse only when I receive money, and not when I do not receive it: rather, I offer myself to both rich and poor alike for questioning, and if anyone wishes to hear what I say, he may answer me. And whether any of them becomes an upright man or not, I would not justly be held responsible, since I have never promised or taught any instruction to any of them. If someone says that he has ever learned from me or heard privately anything that everyone else did not, know well that he does not speak the truth. But why, then, do some enjoy spending so much time with me? You have heard, men of Athens; I told you the whole truth. It is because they enjoy hearing men examined who suppose they are wise, but are not. For it is not unpleasant (Ap. 32 e-33 c).

[37] Cornelius Castoriadis. "Unending Interrogation," in The Rising Tide of Insignificancy (The Big Sleep), translated and edited anonymously, http://www.notbored.org/cornelius-castoriadis.html, December, 2003, pp. 276-77.

[38] Cornelius Castoriadis. "Unending Interrogation," in The Rising Tide of Insignificancy (The Big Sleep), translated and edited anonymously, http://www.notbored.org/cornelius-castoriadis.html, December, 2003, pp. 276-77.

[39] Cornelius Castoriadis, "The Greek Polis and the Creation of Democracy" in Philosophy, Politics, Autonomy, Edited by David Ames Curtis, New York and Oxford (Oxford University Press, 1991), pp. 101-02.

[40] Cornelius Castoriadis. "Unending Interrogation," in The Rising Tide of Insignificancy (The Big Sleep), translated and edited anonymously, http://www.notbored.org/cornelius-castoriadis.html, December, 2003, pp. 276-77.

[411 Plato, Phaedo, translated and edited by David Gallop (Oxford and New York: Oxford University Press, 1993), p. 38.

[42] Cornelius Castoriadis, "What is Democracy" in Figures of the Thinkable, translated by Helen Arnold, Stanford, California (Stanford University Press, 2007), 
p. 150. Emphasis added.

Dr. John F. Humphrey is an assistant professor in the North Carolina Agricultural and Technological State University, College of University Studies. His research interests are in the history of philosophy. He has published a translation of Joan Stambaugh's Untersuchungen zur Problem der Zeit bei Nietzsche under the title of The Problem of Time in Nietzsche. He is a member of the American Philosophical Association and the National Forensic League. 